\title{
FINE ROOT STANDING STOCK AND PRODUCTION IN YOUNG BEECH AND SPRUCE STANDS
}

\author{
Bohdan KonôPKA ${ }^{1,2}$, Jozef PajtíK ${ }^{1,2}$, MiRiam Malová $^{1}$ \\ ${ }^{1}$ National Forest Centre - Forest Research Institute Zvolen, T. G. Masaryka 2175/22, \\ SK-96092 Zvolen,e-mail: bkonopka@nlcsk.org,pajtik@nlcsk.org, malova@nlcsk.org \\ ${ }^{2}$ Czech University of Life Sciences Prague, Faculty of Forestry and Wood Sciences, Kamýcká 129, \\ CZ - 16521 Praha 6 - Suchdol
}

KonôPka, B., PaJtík, J., Malová, M., 2013: Fine root standing stock and production in young beech and spruce stands. Lesnícky časopis - Forestry Journal, 59(3): 163-171, 2013, 3 fig., tab. 5, ref. 27, ISSN 0323 - 1046. Original paper.

\begin{abstract}
Fine roots (defined by a maximum diameter of $2 \mathrm{~mm}$ ) and assimilatory organs are the compartments which rotate carbon much faster than any other tree part. We focused on quantification of fine roots in young European beech and Norway spruce trees growing under the same ecological conditions. Standing stock of fine roots was estimated by soil coring during 2009 - 2012. Fine root production was established by the in-growth bag method. Standing stock and productions of fine roots were comparable in both tree species. The quantity of fine root biomass (at a soil depth of $0-50 \mathrm{~cm}$ ) varied inter-annually between 6.08 and $7.41 \mathrm{t}$ per ha in the beech and from 5.10 to $6.49 \mathrm{t}$ per ha in the spruce stand. Annual production of fine roots (soil depth of $0-30 \mathrm{~cm}$ ) was between 1.11 and $1.63 \mathrm{t} \mathrm{ha}^{-1}$ in beech and between 0.95 and 1.54 t.ha $^{-1}$ in spruce. We found that fine root standing stock at the beginning of each growing season was related to climatic conditions in the previous year. Annual fine root production was influenced by the climatic situation of the current year. In general, a maximum standing stock of fine roots as well as a relatively slow fine root turnover is expected in young forest stands. Whereas production of fine roots prevailed over mortality in a favorable year (sufficiency of precipitations and slightly above-average temperatures in 2010), there was a reverse situation in an unfavorable year (drought episodes in 2011). We concluded that although both forest types represented contrasting turnovers of assimilatory organs (once a year and once in 5 years in beech and spruce respectively), fine root turnover rates were very similar (approx. once per four years).
\end{abstract}

Keywords: Fagus sylvatica, Picea abies, fine roots, turnover, production

\section{Introduction}

Since assimilatory organs and the tiniest root fragments are the most dynamic compartments, they represent some of the most dominant "paths" for biochemical cycles (HelmisaAri et al., 2002). Besides other chemical elements and compounds, this significantly contributes to carbon cycling. This element became a target of intensive interest to scientists especially due to ongoing climate change, because carbon in oxide form contributes to temperature regulation, leading to other modifications of global atmosphere (Dixon et al., 1994). At the same time, JANSSENS et al. (2005) pointed out that the forests of Europe play an important role in the sequestration of carbon. Therefore it is necessary to obtain exact informa- tion not only about tree compartments, which fix carbon for a long time (i.e. coarse branches, stem, roots), but also about those, which fix carbon for some months or for a few years maximum (assimilatory organs and fine roots - those fractions are usually characterized by an upper diameter of $2 \mathrm{~mm}$ ).

While the procedures for estimating standing stock of assimilatory organs are relatively apparent (for instance by means of entire tree or some representative tree part sampling, ultimately by litterfall collection), the quantification of fine roots is more difficult. The main problem is related to the fact that all root fractions are hidden in the soil, which complicates accessibility to them. "Traditional" approaches based on the excavation of whole root 
systems, or its representative parts, for the quantification of fine roots are unsuitable because of potential breakages and partial losses (BöHM, 1979). Therefore, methods such as soil cores or soil blocks are more applicable (e.g. Persson \& Stadenberg, 2010). Consequently, fine roots are separated from the soil samples in laboratory conditions and the amount of fine roots from the known soil volume is up-scaled for a stand area unit base. In fact, results relating to fine root standing stock originating from a variety of authors differs considerably (FINÉR et al., 2007). That is a consequence of high variability of its mass among site conditions, temporal and spatial variability due to environmental situations, heavy seasonal dynamics, or sensitivity to stand characteristics and forestry management (JALOVIAR, 2010).

Patterns of foliage production and turnover are relatively well-known. In the case of deciduous trees the turnover represents an annual cycle, in evergreen trees the turnover takes a few years (approximately $3-6$ years). Much less is known about the production and turnover of fine roots. Nevertheless, existing works show broad range values of estimates for these processes (see e.g. NoGUCHI et al., 2007; YUAN \& CHEN, 2010). The principal problem for the quantification of fine root production lies in a parallel course of three processes; production, mortality and decomposition (or disappearance) during a growing season (PERsson, 1980). Therefore, fine root production cannot be established via "conventional" approaches, i.e. as a difference between standing stocks found in two time horizons.

The term "turnover" usually represents the production over existing standing stock, or how many times the current standing stock is replaced by new biomass in one year (LUKAC, 2012). At the same time, turnover of fine roots represents a reverse value to lifespan (e.g. turnover twice a year equals a lifespan of 0.5 year). The possibility of comparing results of fine root turnover originating from a variety of works is impaired. Besides methodological differences in the derivation of input items (standing stock and production), inconsistencies in the definition of turnover is also a problem. Individual authors prefer minimum, mean, or maximum standing stock as the denominator, which unsurprisingly brings contrasting results (KonÔPKA et al., 2006). A recent paper from BRUNNER et al. (2013) synthesized results concerning fine root turnover in European beech and Norway spruce from many authors. The paper indicates that fine root turnover in beech and spruce varied mostly in the range of 0.9 and 1.1 per year. The authors suggest that the most suitable way to calculate fine root turnover is a ratio between the production and the average standing biomass stock.

The abovementioned gaps in scientific knowledge inspired a field observation study of which the present paper is an integral part. We aim to estimate fine root standing stock and turnover in young beech and spruce stands grown under the same site conditions. The species were chosen as dominant forest trees in Central Europe, but also as a typical representation of vegetation with contrasting strategies of foliage turnover (deciduous versus evergreen). Moreover, beech and spruce are contrasting from the climate change perspective; beech in comparison with spruce is assumed to be more suitable for a major part of central Europe territory for the changing environmental conditions (e.g. LinDNER et al., 2010).

We postulated a hypothesis that contrasting patterns of foliage turnover would be mirrored by differences in fine root turnover. Further, we hypothesize that interannual differences in fine root standing stocks and productions would be apparent at the site. To place our findings in physiological setting, we compared the temporal changes of fine root processes to abiotic ambient characteristics (specifically air temperature and precipitations).

\section{Material and Methods}

This research was conducted over the period of 2009 - 2012 at the "Vrchslatina" locality, which is located at an altitude ca $960 \mathrm{~m}$ above sea level (coordinates: $48^{\circ}$ $38^{\prime}$ ' $55^{\prime} \mathrm{N}, 19^{\circ} 36^{\prime}$ ' $07^{\prime} \mathrm{E}$ ). The locality is situated in the west-most part of the Veporské Hills, the bedrock is mostly composed of granodioirite. The soil is a eutric cambisol with a low portion of skeleton, mostly sandyloam. The $\mathrm{C} / \mathrm{N}$ ratio in the upper $10 \mathrm{~cm}$ of soil is about $17, \mathrm{pH}$ (in $\mathrm{CaCl}$ ) values were $4.5,5.3$ and 4.5 at the depths of $0-10 \mathrm{~cm}, 10-35 \mathrm{~cm}$ and $35-65 \mathrm{~cm}$. The site represents an ecological optimum for beech growth and the southern boundary for the natural occurrence of spruce in Slovakia.

Measurements presented in this paper took place in forest complexes composed exclusively of young beech or spruce (see also KonôPKA et al., 2013). The site is forested by nearly even-age stands originating from natural regeneration under a sparse tall forest. The patches of beech and spruce utilized in this research were directly neighboring. Some open areas among the forest stands were colonized by grass communities with a dominancy of bushgrass (Calamogrostis epigejos).

In 2009, five circular plots in beech and five in spruce stands were established and all trees inside the plots were labeled. A radius of the plots was established with regard to stand density to include between 30 and 50 individual trees (hence, the radius varied between 0.7 and $1.0 \mathrm{~m}$ in beech and from 0.7 to 1.0 in spruce). The trees on the plots were measured every year for height and diameter at ground level. We did not use standard measurements of diameter at $\mathrm{DBH}$, because some trees had not reached this height yet. The recorded tree parameters were used to calculate basic stand characteristics (the detailed procedure is given in PАJTík et al., 2013). Moreover, a set of beech and spruce trees were sampled to construct allometric equations for aboveground tree compartments 
(foliages, branches and stem) as well their standing stock and yearly production (see PAJTík et al., 2013).

The quantification of fine roots in beech and spruce was performed by two methods: (i) soil coring and (ii) ingrowth bags. Thus, every year from 2009 - 2012 shortly after thawing out the soil (i.e. in the middle part of April), 15 soil cores from beech and another 15 from spruce stands were sampled. We used iron auger with an inner diameter of $7 \mathrm{~cm}$. The soil cores were taken down to a soil depth of $50 \mathrm{~cm}$; they were split into five $10-\mathrm{cm}-$ long columns and inserted in to plastic bags. The samples were stored in deep-freeze until further processing.

The in-growth bags were cylindrically shaped plastic nets with a mesh size of $2 \times 2 \mathrm{~mm}$. Their inner diameter was $7 \mathrm{~cm}$ and their length $30 \mathrm{~cm}$. Our previous studies showed that it was technically difficult to harvest ingrowth bags longer than $30 \mathrm{~cm}$. Every year, in the beginning of the growing season, 30 in-growth bags in the beech stand and 30 in the spruce stand were inserted in to $30 \mathrm{~cm}$ deep holes drilled by the auger. The insides of the bags were filled up with quartz sand. Then, half the number of the bags were harvested at the end of the growing season of the same year and half the number were harvested at the end of the growing season of the consecutive year ("1-year" and "2-year" bags, hereafter). The ingrowth bags were inserted in to plastic sacks and deep frozen.

The soil cores were thawed on the day of further processing. All fine roots (diameter up to $2 \mathrm{~mm}$ ) were separated using tweezers. Roots over $2 \mathrm{~mm}$ and those which did not originate from beech or spruce (bushes and herbs) were excluded. The fine roots of the target trees were sorted into live (biomass) and dead (necromass). To distinguish live roots from dead ones, characteristics like: color, mechanical properties of tissues, cohesion between periderm and cortex, status of structure and morphology in root clusters were utilized. The sorted fine roots were carefully washed and placed in paper envelopes, then, dried in an oven at $85^{\circ} \mathrm{C}$ for 24 hours. The dried roots were weighed with a precision of $10^{-4} \mathrm{~g}$. The weights of the fine roots were expressed for soil depths of $0-10,10-20,20-30,30-40$ and $40-50 \mathrm{~cm}$ and up scaled in tons per hectare of the stand area.

In-growth bags were processed in a similar way to the soil cores. Here, almost exclusively live fine roots were found. At the same time, data on fine roots was found for the entire length of the bags (i.e. soil depth $0-30 \mathrm{~cm}$ ). Biomass of fine roots represents more or less their annual production in the ecosystem. Since we found out, in previous experiments, that beech and spruce have contrasting strategies in terms of colonizing new competition-free spaces, two series of in-growth bags were applied. Two series of the bags allowed two different ways to estimate fine root production. The first approach is based on 1-year in-growth bags only. The second approach uses fine production differences ("delta", hereafter) between fine root biomass in 2-year bags found in the current year and fine root biomass in 1-year bags harvested in the previous season. Definitive production of fine roots was calculated as an average value from both methods.

Since we had data on fine root standing stock for both biomass and necromass in two consecutive years, it was possible to also calculate the mortality of fine roots in the period (in fact, this is just a rough estimate, not an exact quantification). Mortality can be calculated as follows. First, we add standing stocks of fine roots for the beginning of the growing season and the production of the same year. Then we subtract standing stocks of fine roots in the beginning of the growing season for the consecutive year from the first total. In our case, the available data allowed the calculation of fine root mortality for 2010 and 2011.

As well as measurements done on the research plots, to make our interpretation of fine root standing stock and production more integrated, all available information about air temperatures and precipitations were also utilized. Specifically, we implemented data originating from the metrological station in Lom nad Rimavicou (Slovak Hydro-Meteorological Institute), which is situated approx. $3 \mathrm{~km}$ from our research site, both are at very similar altitudes. We used monthly means of air temperatures and sums of precipitations in the spring and summer seasons (from April to September). These months represent a part of the growing season that physiological activities of beech and spruce fine roots are most intensive (see for instance KonôPKA, 2009).

Inter-annual differences between the values of fine root standing stocks of fine root biomass or necromass with regard to soil depths were compared by ANOVA. Significant differences were tested by Tukey's HDS test (for $\alpha=0.05$ ). Statistical analyses were performed by JMP 6.0 software (SAS Institute).

\section{Results and discussion}

Dynamic changes in above-ground biomass were found in both beech and spruce young stands (Table 1). The number of trees decreased significantly - from 151 thousand individuals per ha (2009) to 125 thousand (2012) in the beech and from 176 thousand individuals per ha (2009) to 98 thousand (2012) in the spruce. It was interesting that the number of trees per ha in the year of the plots selection (2009) was very similar in both stands. Moreover, similar values were also found in the case of average stem volume. Sharp inter-annual increases were recorded for average stand height and diameter as well as for mean stem volume. In the years 2009 - 2012, average stand height increased by $66 \%$, diameter by $41 \%$ and stem volume by $255 \%$ in the beech, and in the spruce stand it was by $75 \%, 72 \%$ and $283 \%$ for the average stand height, diameter and stem volume, respectively.

While dimensions of aboveground parts of the stands grew, fine root standing stock did not show such a clear 
Table 1. Stand characteristics of beech and spruce stands in $2009-2012$

\begin{tabular}{|c|c|c|c|c|c|c|}
\hline \multirow{2}{*}{ Stand characteristics } & \multicolumn{2}{|c|}{ Year 2009} & \multicolumn{2}{|c|}{ Year 2012} & \multicolumn{2}{|c|}{ Difference (2012 - 2009) } \\
\hline & beech & spruce & beech & spruce & beech & spruce \\
\hline Number of trees $\left[10^{3}\right.$ per ha $]$ & 157 & 176 & 125 & 98 & -32 & -78 \\
\hline Mean height $[\mathrm{cm}]$ & 225 & 172 & 373 & 301 & 148 & 129 \\
\hline Mean diameter $\mathrm{d}_{0}[\mathrm{~cm}]$ & 1.89 & 1.88 & 2.67 & 3.23 & 0.78 & 1.35 \\
\hline Mean stem volume $\left[\mathrm{cm}^{3}\right]$ & 233 & 225 & 595 & 860 & 362 & 635 \\
\hline
\end{tabular}

Table 2. Standing stock of live (biomass) and dead (necromass) fine roots (t.ha-1) and their ratio in the $0-50 \mathrm{~cm}$ soil depth

\begin{tabular}{|l|c|c|c|c|c|c|}
\hline \multirow{2}{*}{ Year } & \multicolumn{2}{|c|}{ Root biomass } & \multicolumn{2}{c|}{ Root necromass } & \multicolumn{2}{c|}{ Necromass / biomass } \\
\cline { 2 - 7 } & beech & spruce & beech & spruce & beech & spruce \\
\hline 2009 & 6.18 & 6.27 & 1.28 & 1.19 & 0.21 & 0.19 \\
2010 & 6.59 & 6.49 & 1.30 & 1.56 & 0.20 & 0.24 \\
2011 & 7.41 & 6.16 & 1.07 & 1.09 & 0.14 & 0.18 \\
2012 & 6.08 & 5.10 & 0.88 & 0.98 & 0.14 & 0.19 \\
\hline Average & 6.57 & 6.01 & 1.13 & 1.21 & 0.17 & 0.20 \\
\hline
\end{tabular}

tendency (Table 2). In the beech, a significant annual increase of fine root biomass was found in the years 2009 - 2010 - 2011; however it then, decreased in 2012. In the spruce, a slight increase of fine root biomass occurred between 2009 and 2010 we then recorded a large decrease in 2011 and 2012. Fine root necromass had a decreasing tendency between 2010 and 2011 but more significantly from 2011 to 2012 in the beech. Fine root necromass in spruce, on the other hand, showed a significant inter-annual increase between 2009 and 2010 and then a very sharp decrease in 2011. Inter-annual changes were also recorded for the rates between quantities of live and dead fine roots that were expressed in a necromass to biomass ratio. The largest differences were between the two initial years and the consecutive two years (i.e. 2009 and 2010 versus 2011 and 2012).

The smallest fine root biomass in beech and spruce were in 2012 (6.08 and $5.10 \mathrm{t}$ per ha, respectively) this could relate to an exceptionally dry August and September in 2011 (at the same time, a decline in diameter increments of both the beech and spruce were recorded; BošEL'A et al., 2013). The maximum biomass of fine roots in the beech was in 2011 (7.41 t.ha-1) and in the spruce in 2010 (6.49 t.ha-1). The average standing stock of fine root biomass for the entire period of study was larger in the beech (6.49 t.ha $\left.\mathrm{t}^{-1}\right)$ than in the spruce $\left(6.01 \mathrm{t}^{-h a^{-1}}\right)$. These findings are in accordance with the results from FINÉR et al. (2007) proving that by using all-European data, European beech make up a larger standing stock of fine root biomass (average of 3.89 t.ha $^{-1}$ ) than Norway spruce (2.97 t.ha-1).

It is rather difficult to determine the most influential factors governing inter-annual changes in fine root biomas and necromass. We contend that two underlying factors are involved: changes in fine root quantity caused by stand growth and by external (abiotic) factors, especially temperatures and precipitations. For the first factor, we would like to point out the conclusions of VoGT et al. (1987), who found that fine root biomass in young stands of temperate forests increased only in the very initial stages. Fine root biomass reached a maximum in the time consistent with the early stage of canopy closure. Then, fine root biomass decreased on fertile sites or remained at a rather steady level in poor soils. Since the young stands in Vrchslatina were excessively stocked, they reached nearly full canopy closure by the time the experiment began. We cannot refute the possibility that the maximum biomass of fine roots reached its maximum due to natural stand development in 2010 (spruce) and 2011 (beech). The stands are growing on rather fertile soils. Hence, we did not expect that the standing stock of fine roots would remain on the same level; rather we assumed its gradual decrease (in accordance with VoGT et al., 1987). This hypothesis is supported by the argument that standing stock of fine roots found in our stands was much larger than values given in the other papers originating from elder beech and spruce stands in Slovakia (e.g. KonôPKA, 2009; JALOVIAR, 2010; KuCBEL et al., 2011) or in a wider European context (FINÉR et al., 2007; BRUnNer et al., 2013).

Inter-annual oscillation of fine root standing stock also relates to abiotic environment factors. All the years during our experiment were warmer than the mean temperature of the reference period 1961 - 1990 (Figure 1). Extraordinarily high amounts of precipitations fell in 2010. Since we quantified standing stock of fine roots at the beginning of each growing season, the actual status reflected the situation of the previous year (especially during the growing season and then in the spring and summer months). Biomass of beech fine roots reached a maximum in 2011 this could relate to the above-normal sum of precipitation in the previous year. Rain occurred 

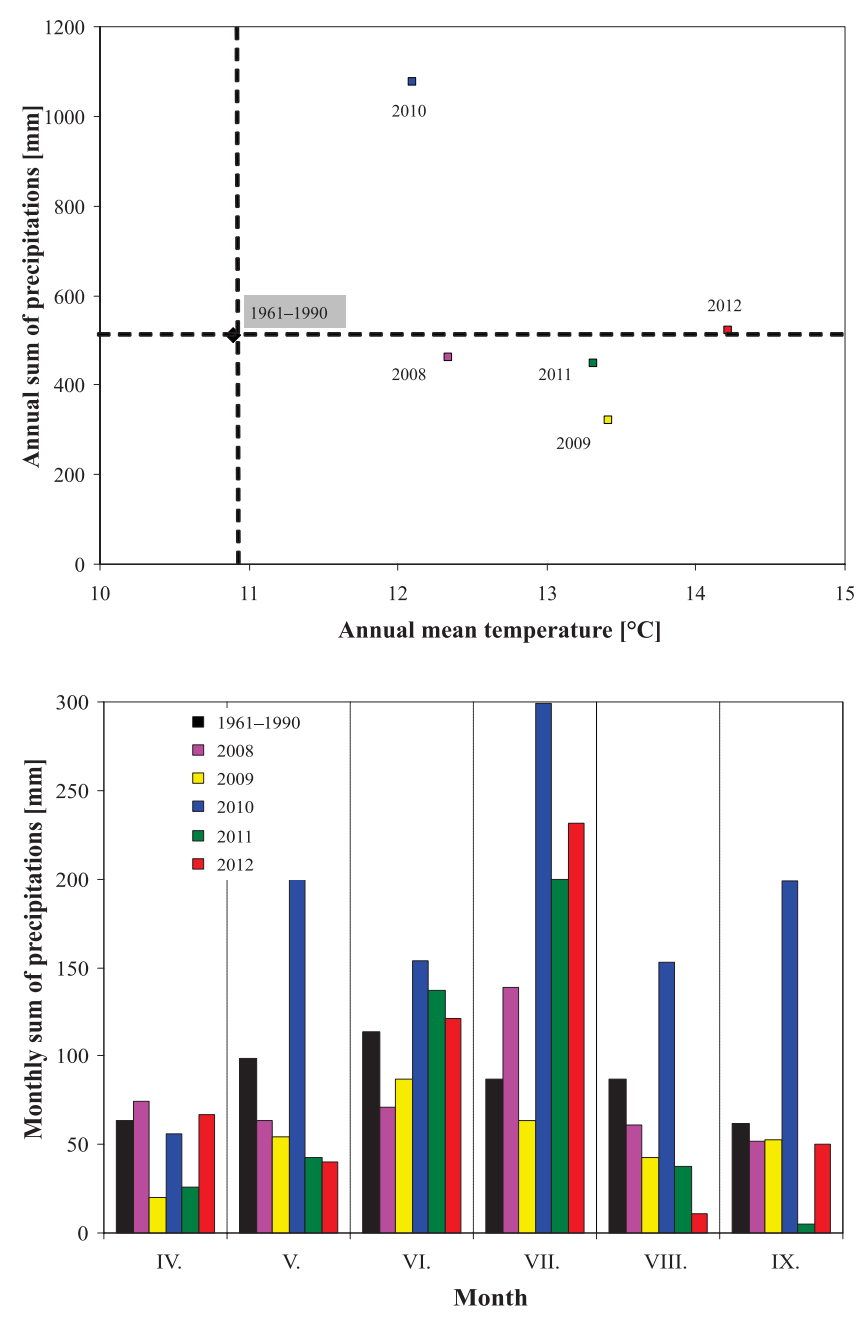

in June and July, together with above-normal air temperatures (Figure 1). However, this phenomenon was not clearly manifested in the spruce stand where fine root standing stock inter-annually tended to decrease (Table 2 ). On the other, hand the minimum level of fine root standing stock was in the spring of 2012 this might relate to an exceptionally dry episode in August and September 2011. In the case of the biomass standing stock of fine roots the difficulty is in the fact that its amount is modified not only by production rate (direct relation) but also by mortality (indirect relation). A similar situation is seen for necromass which is determined not only by input (mortality) but also output (decomposition and disappearance) items.

For both the beech and spruce stands, a rather large inter-annual oscillation of fine root biomass was found at all soil depths (Figures 2 and 3). For soil depths of $0-10 \mathrm{~cm}$, both tree species showed clear inter-annual increases of fine root biomass from 2009 to 2011 (reaching maximum value) and then decreased between 2011 and 2012. For most of the other soil depths, the interannual development of fine root biomass differed from those in the upper soil. The results suggest that climate conditions in these particular years may influence the

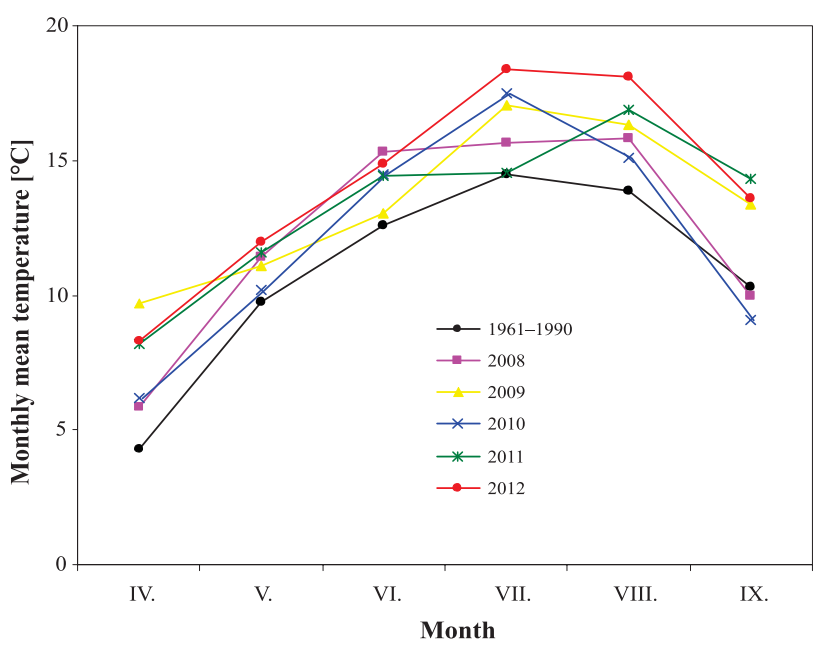

Fig. 1. Average temperature and total sum of precipitations for the spring and summer months in the years of observation and in the long-term data for 1961 - 1990 (upper diagram). Average monthly temperatures (middle diagram), monthly sums of precipitations (downer diagram) in the specific spring and summer months of the years $2008-2012$

fine root quantity of the individual soil layers in specific ways. These findings agree with the conclusions of KONÔPKA \& LUKAC (2013) in mature spruce stands. They found that moderate drought restricted fine root quantity in the upper soil. On the other hand, this loss was partly compensated by an increased root growth in the deeper soil layers. KozLowsKI \& PALLARDY, 1997 suggested that trees' fine roots in the upper soil layers are controlled more by external abiotic factors than those located in deeper soil depths.

Fine root production measured by in-growth bags showed that beech, in comparison with spruce, is faster at the colonization of new, competition-free spaces (1-year bags; Tables 3 and 4). The opposite situation occurred when the bags were left in the soil for 2 years; more fine roots grew in the spruce than in the beech (2-year bags; Tables 3 and 4). The method of 1-year bags suggested that the production of fine roots in the beech was 2.6 time large than in the spruce. The "delta" method (see Material and Methods section) generated the opposite conclusions, that fine root production in the spruce was 1.8 times higher than in the beech. Since the application of the two methods introduced contrasting results, we decided to calculate a definitive production as an average 

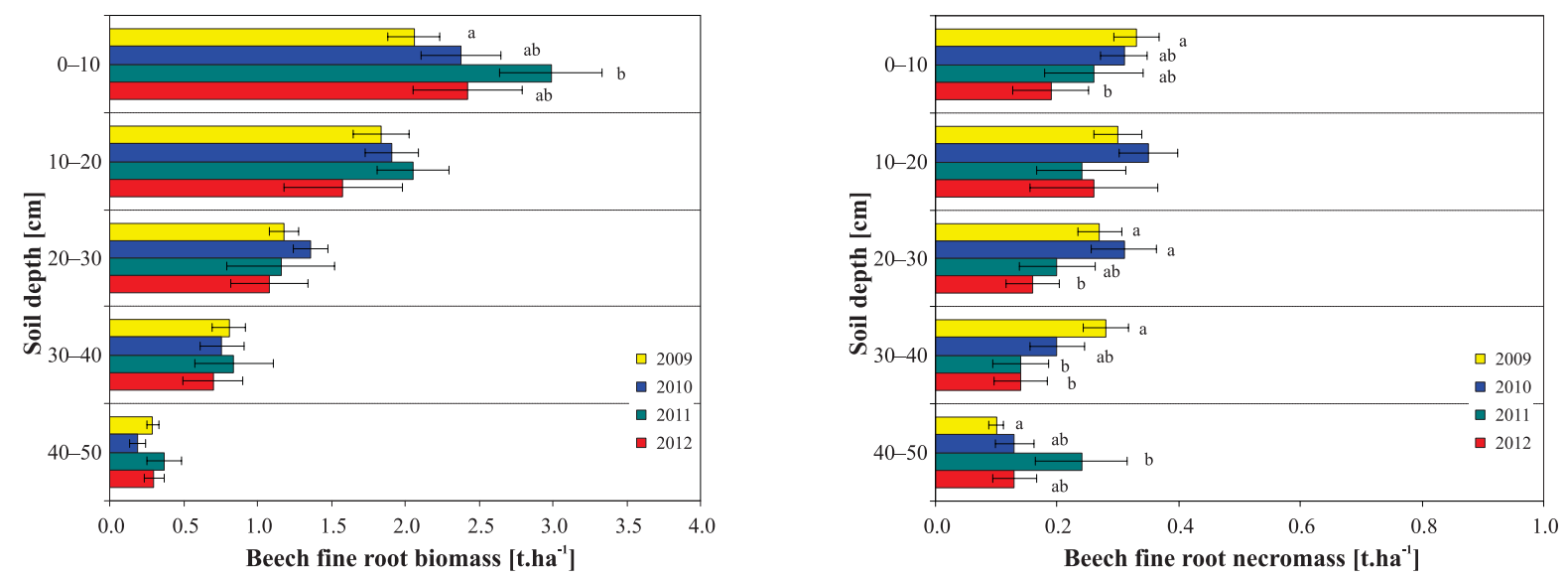

Fig. 2. Standing stock of beech fine roots - biomass (left plate) and necromass (right plate) at the specific soil depths (error bars represent standard errors, different letters express statistical differences in masses of fine roots between the years at the depth level; HSD test with $\alpha=0.05$ )
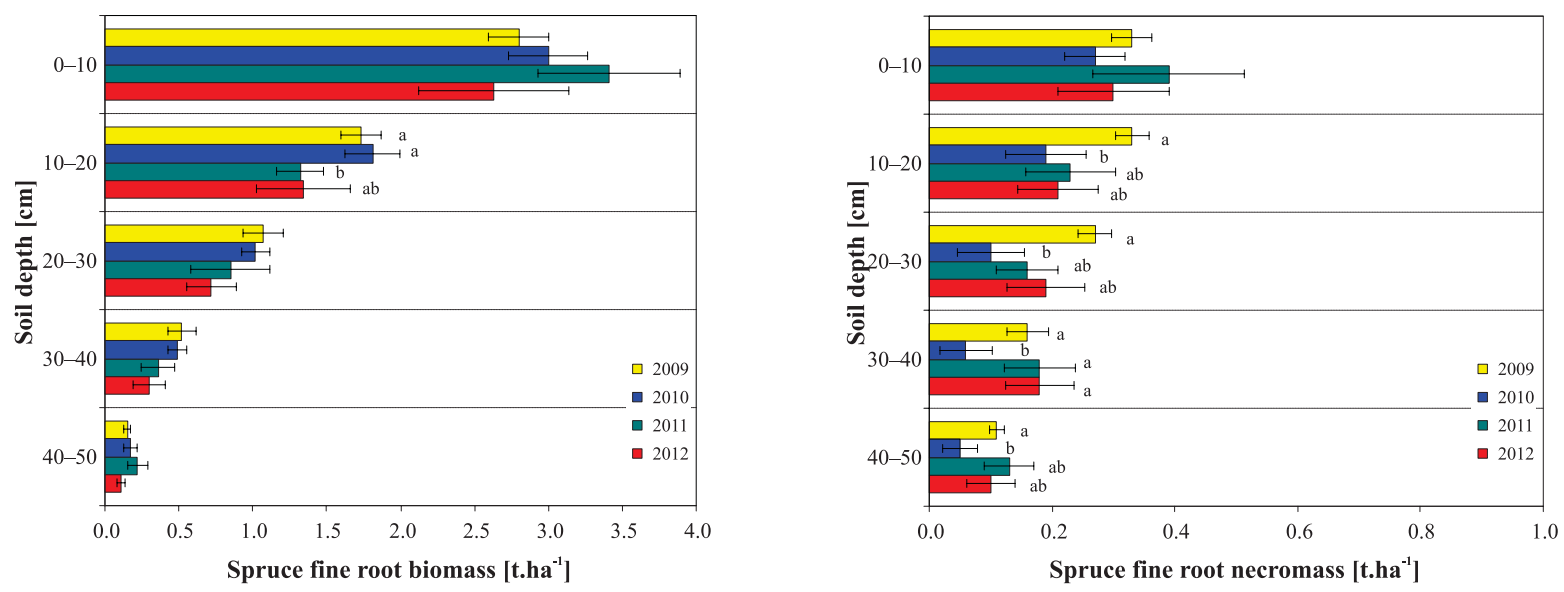

Fig. 3. Standing stock of spruce fine roots - biomass (left plate) and necromass (right plate) at the specific soil depths (error bars represent standard errors, different letters express statistical differences in masses of fine roots between the years at the depth level; HSD test with $\alpha=0.05$ )

from both methods. Doing so, an average annual fine root production in the beech (1.37 t.ha- $\left.{ }^{-1}\right)$ was slightly higher than in the spruce $\left(1.29\right.$ t.ha $\left.^{-1}\right)$. The maximum production of fine roots $\left(1.63\right.$ t.ha-1 $^{-1}$ in the beech and 1.54 t.ha $^{-1}$ in the spruce) was reached in 2010, and the minimum production (1.11 t.ha- in the beech and 0.95 t.ha $^{-1}$ in the spruce) in 2011. We assume that current production relates mainly to climate conditions of the year, especially during the spring and summer months. Thus, maximum and minimum levels of productions occurred with abovenormal precipitations in 2010 (Figure 1A) and rather a dry beginning of the growing season in 2011. Moreover, the annual amplitude of air (soil) temperature is important to fine root production too. For instance experiments of LYR \& HofFMAnN (1967) established that the seasonal course of fine root elongation correlated with soil temperature.

Here, it is necessary to admit that our results on fine root production are proximate (conditions inside the bags are slightly different from the real soil profile), thus, interpretation of the findings must be done with caution. We believe that the results are reliable as they deal with inter-annual tendencies (increase or decrease) because the in-growth bags were prepared and installed every year in the same way. Since we have information about standing stock and production of fine roots in the years of 2009 - 2012, it was possible to calculate its turnover. Fine root turnover oscillated between 0.18 and 0.29 per year in the beech and from 0.17 to 0.30 per year in the spruce (Table 5). Average values of turnover for the period 2010 - 2012 were very similar in both species, i.e. 0.25 per year and 0.24 per year, in beech and spruce, respectively (these represent a lifespan of cca 4 years). This value is lower than shown in most other papers. Reviewing data from all-European countries 
Table 3. Fine root biomass in the beech stand measured in 1-year and 2-year in-growth bags (in t.ha-1; together for the soil depth of $0-30 \mathrm{~cm})$ and an annual production estimate $\left(\mathrm{t}^{-h^{-1}} \cdot \mathrm{year}^{-1}\right)$

\begin{tabular}{|l|c|c|c|c|}
\hline \multirow{2}{*}{ Year } & Root mass & Root mass & Root mass & \multirow{2}{*}{ Mean annual root production*** } \\
\cline { 2 - 4 } & 1-year & 2-year & difference* & - \\
2009 & 2.73 & - & - & 1.63 \\
2010 & 1.76 & 4.23 & 1.50 & 1.11 \\
2012 & 1.42 & 2.55 & 0.79 & 1.36 \\
\hline Average & 1.75 & 2.39 & 0.97 & 1.37 \\
\hline
\end{tabular}

*difference between biomass in 2-year in-growth bags (year $x$ ) and biomass in 1-year bags (year $x$-1).

**calculated as the average value from biomass in 1-year in-growth bags and biomass determined by difference ("delta approach").

Table 4. Quantity of fine roots in the spruce stand in 1-year and 2-year in-growth bags (in t.ha-1; together for the soil depth of

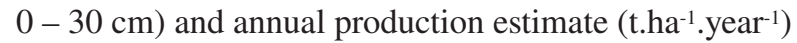

\begin{tabular}{|c|c|c|c|c|}
\hline \multirow{2}{*}{ Year } & \multicolumn{3}{|c|}{ Root mass } & \multirow{2}{*}{ Mean annual root production** } \\
\hline & 1-year & 2-year & difference* & \\
\hline 2009 & 0.86 & - & - & - \\
\hline 2010 & 0.82 & 3.11 & 2.25 & 1.54 \\
\hline 2011 & 0.58 & 2.13 & 1.31 & 0.95 \\
\hline 2012 & 0.60 & 2.75 & 2.17 & 1.39 \\
\hline Average & 0.72 & 2.66 & 1.91 & 1.29 \\
\hline
\end{tabular}

*difference between biomass in 2-year in-growth bags (year $x$ ) and biomass in 1-year bags (year $x$-1).

**calculated as average value from biomass in 1-year in-growth bags and biomass determined by difference ("delta approach") in biomasses.

Table 5. Fine root turnover (times per year) in the beech and spruce, their mortality (t.ha-1) and ratio between mortality and production at the soil depth of $0-30 \mathrm{~cm}$

\begin{tabular}{|c|c|c|c|c|c|c|}
\hline \multirow{2}{*}{ Year } & \multicolumn{2}{|c|}{ Turnover } & \multicolumn{2}{|c|}{ Mortality } & \multicolumn{2}{|c|}{ Mortality / production } \\
\hline & beech & spruce & beech & spruce & beech & spruce \\
\hline 2009 & - & - & - & - & - & - \\
\hline 2010 & 0.29 & 0.26 & 1.17 & 1.28 & 0.72 & 0.83 \\
\hline 2011 & 0.18 & 0.17 & 2.02 & 1.84 & 1.82 & 1.94 \\
\hline 2012 & 0.27 & 0.30 & - & - & - & - \\
\hline Average & 0.25 & 0.24 & 1.60 & 1.56 & 1.27 & 1.39 \\
\hline
\end{tabular}

(BRUNNER et al., 2013) showed that average turnovers for both beech and spruce were approx. once a year. The slow fine root turnover may be caused by favourable soil conditions (see also TATENO et al., 2004), but also by the potential underestimation of fine root production (and hence turnover) due to the applied methodological approach. Moreover, a potential reason for this might be the expansive nature of these stands. Here, the standing stock of fine roots is about maximum and the trees gradually preferred to allocate carbohydrates to aboveground compartments under severe competition for light. This theory is supported by the results dealing with the ratio between standing stock of fine roots and foliages (the data on the foliages originates from РАлті́K et al., 2013). Whereas in 2009 this ratio was 1.92 for the beech and 0.46 for the spruce, in 2011 the same ratio showed values of 1.55 and 0.34 in the beech and spruce, respectively.
Similar inter-annual tendency (shifting to aboveground biomass) was found for the ratio between production of fine roots and foliages (combined with results with PAJTíK et al., 2013). While in 2010 this ratio was 0.34 in the beech and 0.28 in the spruce, the ratio was only 0.18 and 0.17 in beech and spruce, respectively. This means that the young stands of beech and spruce (in terms of carbon fast rotating compartments, i.e. foliages and fine roots) during our experiment allocated more carbohydrates to aboveground than belowground biomass. Consequently, the trees increased the ratio between foliage litter ("on the ground") and fine root litter ("in the soil"). The results of РАлті́K et al. (2013) showed that the standing stock of foliages was much larger in the spruce than in the beech. On the other hand, litter from foliages was due to contrasting lifespans, higher in the beech than in the spruce by cca $30 \%$ (unpublished data). 
Fine root mortality in the beech and spruce could be calculated because the base data (i.e. standing stock in two consecutive years and production of the first of them) was only for 2010 and 2011 (Table 5). It is necessary to point out that this calculation is based on a simplification, because seasonal fluctuations of standing biomass were not taken into account (more precise results might be obtained by using the decision matrix from FAIRLEY \& AleXANDER, 1985 - however, repetitive sampling for the estimation of biomass and necromass standing stock throughout current year is necessary). Whereas production prevailed over mortality in 2010 (mortality to production ratio was 0.72 in the beech and 0.83 in the spruce), the reverse situation occurred in 2011 (1.82 in the beech and 1.94 in the spruce). Here contrasts in inter-annual courses could be explained by metrological conditions, specifically the extraordinarily rainy year of 2010, contrariwise, a below-normal sum of precipitations in April, May and August 2011. The abiotic environment (including moisture and temperature of soil) governs not only the production and mortality of fine roots, but also the decomposition of necromass. While moist and warm conditions stimulate microbial activities, and consequently decomposition of organic matters, drought or low temperature decelerates this process (see for instance Goncalves \& CARLYle, 1994; KonôPKa et al., 2005).

\section{Conclusion}

This study shows that fine roots make up a significant quantity of biomass in forest ecosystems. The amount of fine root biomass decreased with the soil depth, this tendency was not so clear for fine root necromass. We recorded inter-annual differences in both fine root biomass and necromass at specific soil depths. Total standing stocks of fine roots in the young stands of beech and spruce were higher than results from some other authors, which prevailingly come from older forest stands. In the period of 2009 - 2012, a sharp increase in the standing stock of aboveground tree parts including foliages (fast rotating compartments) was recorded. On the other hand, fine root standing stock oscillated inter-annually and did not manifest a clear increase. These results suggest an increase in the ratio between litter originating from foliages and that from fine roots.

\section{Acknowledgement}

The study was supported through APVV-0268-10, APVV-0273-11 and APVV-0111-10 projects awarded by the Slovak Research and Development Agency, also partly supported by the Ministry of Agriculture of the Czech Republic under the contract No. QIIO2A079.

\section{References}

Bošela, M., PAJTík, J., KonÔPKA, B., ŠEBeŇ, V., VIDA, T., 2013: Modelling effects of weather condition on seasonal dynamics of the stem circumference increment in a mixed stand of Norway spruce and European beech. Lesnícky časopis - Forestry Journal, 59(3):180-188.
BöHм, W., 1979: Methods of Studying Root Systems. Berlin, SpringerVerlag, $188 \mathrm{pp}$.

BRUNNER, I. et al., 2013: Fine-root turnover rates of European forests revisited: an analysis of data from sequential coring and ingrowth cores. Plant and Soil, 362(1): 357-372.

Dixon, R.K. et al., 1994: Carbon pools and flux of global forest ecosystems. Science, 263: 185-190.

FaIrley, R.I., AleXANDER, I.J., 1985: Methods of calculating fine root production in forests. In: FitTER, A.H. (ed): Ecological Interactions in Soil. Special Publication of the British Ecol. Soc., p. 37-42.

FINÉR, L. et al., 2007: Variation in fine root biomass of tree European tree species: Beech (Fagus sylvatica L.), Norway spruce (Picea abies Karst.) and Scots pine (Pinus sylvestris L.). Plant Biosystems, 141(3): 394-405.

Goncalves, J.L.M., Carlyle, J.C., 1994: Modeling the influence of moisture and temperature on net nitrogen mineralization in a forested sandy soil. Soil Biology Biochemistry, 26: 1557-1564.

HelmisAaRi, H.S. et al., 2002: Below- and above-ground biomass, production and nitrogen use in Scots pine stand in eastern Finland. Forest Ecology and Management, 165: 317-326.

JALOVIAR, P., 2010: Produkcia a morfologické znaky jemných koreňov smreka. Zvolen: Technická univerzita vo Zvolene, $71 \mathrm{pp}$.

JANSSENS, I.A. et al., 2005: The carbon budget of terrestrial ecosystems at country-scale - a European case study. Biogeosciences, 2: $15-26$.

Konôpka, B., Janssens, I.A., Curiel Yuste, J., Ceulemans, R., 2005: Comparison of fine root dynamics in Scots pine and Pedunculate oak in sandy soil. Plant and Soil, 276: 33-45.

Konôpka, B., Janssens, I.A., Curiel Yuste, J., Ceulemans, R., 2006: Fine root turnover in a temperate Scots pine forest. Lesnícky časopis - Forestry Journal, 52(1-2): 107-117.

KonÔPKA, B., 2009: Differences in fine root traits between Norway spruce (Picea abies [L.] Karst.) and European beech (Fagus sylvatica L.) - A case study in the Kysucké Beskydy Mts. Journal of Forest Science, 55(12): 556-566.

KonÔPKA, B., LuKac, M., 2013: Moderate drought alters biomass and depth distribution of fine roots in Norway spruce. Forest Pathology, 43(2): 115-123.

KonôPKa B., Pajtík, J., ŠEbeŇ, V., BošEla, M., Máliš, F., Priwitzer, T., Pavlenda, P., 2013: The Research Site Vrchslatina - an experimental design and the main aims. Lesnícky časopis - Forestry Journal, 59(3): 203-213.

Kozlowski, T.T., Pallardy, S.G., 1997: Physiology of Woody Plants. San Diego, Academic Press, 411 pp.

KuCbel, S., JALOVIAR P., ŠPIŠÁK, J., 2011: Quantity, vertical distribution and morphology of fine roots in Norway spruce stands with different stem density. Plant Root, 5: 46-55.

LinDNER, M. et al., 2010: Climate change impacts, adaptive capacity, and vulnerability of European forest ecosystems. Forest Ecology and Management, 259(4): 698-709.

LuKaC, M., 2012: Fine root turnover. In: Mancuso, S. (ed): Measuring Roots. An Updated Approach. Berlin, Springer, p. 363-374.

LYR, H., HofMANN, G., 1967: Growth rates and growth periodicity of tree roots. International Review of Forest Research, 2: 181-236.

Noguchi, K., KonôpKa, B., Satomura, T., Kaneko, S., TaKahashi, M., 2007: Biomass and production of fine roots in Japanese forests. Journal of Forest Research, 12(2): 83-95.

PAJTík, J., KonÔPKa, B., MarušÁK, R., 2013: Above-ground net primary productivity in young stands of beech and spruce. Lesnícky časopis - Forestry Journal, 59(3): 154-162.

Persson, H., 1980: Spatial distribution of fine-root growth, mortality and decomposition in a young Scots pine stand in central Sweden. Oikos, 34: 77-87. 
Persson, H., Stadenberg, I., 2010: Fine-root dynamics in a Norway spruce (Picea abies L.) forest in eastern Sweden. Plant and Soil, 330: 329-344.

TAteno, R., Hishi, T., TAKedA, H., 2004: Above- and belowground biomass and net primary production in a cool-temperate deciduous forest in relation to topographical changes in soil nitrogen. Forest Ecology and Management, 193: 297-306.

Vogt, K.A. et al., 1987: Conifer and angiosperm fine-root biomass in relation to stand age and site productivity in Douglas-fir forests. Journal of Ecology, 75: 857-870.

YuAn, Z.Y., Chen, Y.H., 2010: Fine root biomass, production, turnover rates, and nutrient contents in boreal forest ecosystems in relation to species, climate, fertility and stand age: literature review and meta-analyses. Critical Reviews in Plant Sciences, 29: $104-221$.

\section{Resumé}

V ostatnom období sa výskum venuje jemným frakciám koreňových systémov drevín najmä z dôvodu ich výrazného prínosu pri obehu uhlíka v lesných ekosystémoch. Naše štúdium jemných koreňov (tieto sa definovali maximálnou hrúbkou $2 \mathrm{~mm}$ ) sa sústredilo do bučín a smrečín v štádiu mladina, rastúcich na výskumnom objekte Vrchslatina. Pomocou dvoch metód, konkrétne pôdne vývrty (v hĺbke pôdy $0-50 \mathrm{~cm})$ a vrastavé valce $(\mathrm{v} 0-30 \mathrm{~cm})$ sa zis- tila zásoba biomasy a nekromasy, ako aj produkcia jemných koreňov. Z týchto údajov sa odvodil ich obeh (vyjadrený ako pomer medzi produkciou a zásobou biomasy) a mortalita. Takéto sledovania sa vykonali počas štyroch rokov (2009 - 2012), pritom sa zohladnili aj klimatické pomery, tzn. priemerné teploty vzduchu a úhrny zrážok. Výsledky poukázali na pokles zásoby biomasy jemných koreňov s híbkou pôdy, pritom výraznejší bol pri smreku (tzn. plytšia distribúcia jemných koreňov) než pri buku. Zásoba jemných koreňov bola mierne vyššia $v$ bučine (priemer za roky 2009 - 2012 bol $6,57 \mathrm{t}$ na ha) než v smrečine (6,01 t na ha), pritom medziročne výrazne varírovala. Ročná produkcia jemných koreňov bola vel'mi podobná v obidvoch porastoch (priemer za roky 2009 - 2012 bol 1,37 t na ha za rok v bučine a 1,29 t na ha za rok v smrečine), pritom aj tu sa zistili vel'ké medziročné rozdiely. Kým v roku 2010 prevládala produkcia jemných koreňov nad ich mortalitou, opačná situácia bola v roku 2011. Zásoba, produkcia a mortalita jemných koreňov pravdepodobne súvisela s klimatickými pomermi v jednotlivých rokoch. Zvýšenú mortalitu jemných koreňov spôsobili najpravdepodobnejšie epizódy sucha. V obidvoch porastoch sa zistili podobné obehy jemných koreňov (približne jedenkrát za 4 roky). Pri porovnaní našich výsledkov s inými prácami sa konštatovali vysoké zásoby jemných koreňov, avšak nízke hodnoty ich obehu. Tento stav jemných koreňov pravdepodobne súvisí s mladým vekom sledovaných porastov, resp. s priaznivými pôdnymi pomermi na stanovišti. 